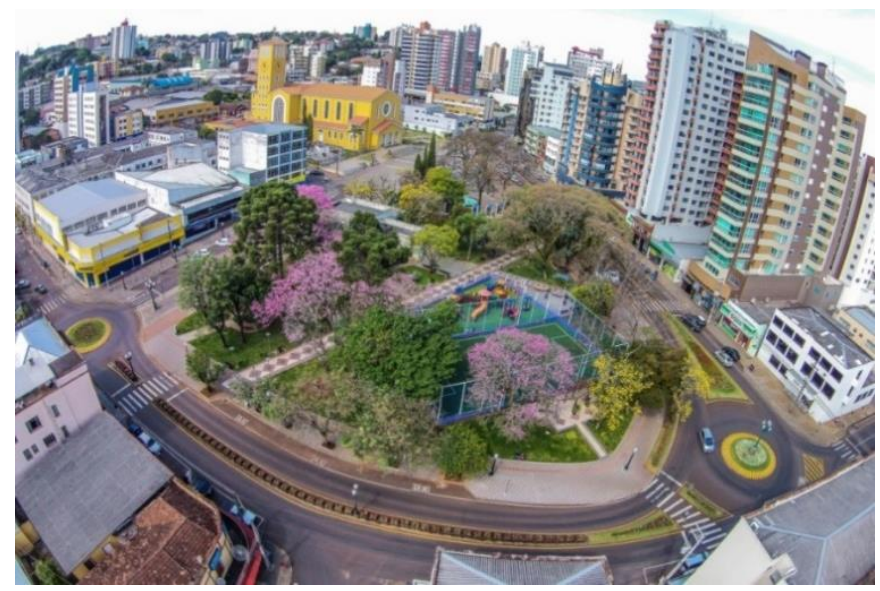

\title{
Dialogismo, sentido e materialidade: a luta pelo espaço público urbano
}

Dialogism, meaning and materiality: the fight for the urban public space

\section{Resumo}

Jozieli Camila Cardenal ${ }^{1}$ Anselmo Pereira de Lima ${ }^{2}$

Este artigo apresenta a perspectiva da produção de enunciados, baseada na teoria da análise dialógica do discurso de Mikhail Bakhtin. Para tanto, apresenta nuances da vida urbana, a partir do movimento estabelecido na Praça Presidente Vargas, situada em Pato Branco (PR). Ao associar concepções da linguística a variáveis da dinâmica urbana, busca-se demonstrar que, ao longo do tempo, o espaço público configura-se enquanto palco de interesses e ações que traduzem diferentes esferas da atividade humana, o que é expresso por meio do caráter material presente no dialogismo.

Palavras-chave: Linguagem. Dialogismo. Materialidade Enunciativa. Espaço Público. Praça Presidente Vargas.

\begin{abstract}
This article presents the production perspective of utterances, based on the dialogical analysis theory of the speech by Mikhail Bakhtin. For this purpose, it presents nuances of the urban life that stems from the movement established at Presidente Vargas Square, located in Pato Branco (PR). By associating conceptions of linguistic to variables of urban dynamics, the aim is to demonstrate that throughout time the public space shapes itself as it gathers interests and actions that translate different spheres of human activity, which is expressed through the material character that is present in dialogism.
\end{abstract}

Keywords: Language. Dialogism. Materiality of the Utterances. Public Space. Presidente Vargas Square.

\footnotetext{
${ }^{1}$ Mestre pelo Programa de Pós-Graduação Stricto Sensu em Desenvolvimento Regional - PPGDR, ofertado pela Universidade Tecnológica Federal do Paraná - UTFPR. E-mail jozieliw@gmail.com. Orcid: https://orcid.org/0000-0003-4385-4375

${ }^{2}$ Prof. Dr. do Programa de Pós-Graduação Stricto Sensu em Letras - PPGL, ofertado pela Universidade Tecnológica Federal do Paraná - UTFPR, Câmpus Pato Branco. E-mail: selmolima@ hotmail.com. Orcid: https://orcid.org/0000-0003-1427-2165
} 


\section{Introdução}

No presente estudo, partimos da perspectiva de que as relações sociais desencadeadas nos espaços públicos, especialmente em praças, oportunizam a interação e a troca de experiências, sendo responsáveis pelo movimento contínuo que reconfigura o tecido urbano local e que, a partir da materialidade que desencadeiam, demonstram demandas e interesses de diferentes esferas sociais. Sendo assim, olhar o espaço público enquanto paisagem inanimada, como se o mesmo fosse resumido apenas a concreto, vidro e metal, é ignorar a sua principal matéria prima: a vida em sociedade.

Assim, este estudo sobre a Praça central de Pato Branco apresenta a linguagem enquanto elo enunciador da existência humana na constituição histórico-social da cidade, por meio da análise de enunciados que, unidos, constroem a história do espaço público enunciativo.

Desde a sua constituição enquanto espaço público, na década de 1930, a Praça Presidente Vargas, situada em Pato Branco, no Sudoeste do Paraná, foi reconfigurada pelo dialogismo desencadeado pelas relações/capitais sociais, seus atores e esferas de poder. Nesse processo, obras de arte passaram a compor o tecido social local a partir do momento em que foram inseridas no principal espaço público da cidade. Assim, não apenas objetos físicos, mas as ações humanas (experiências e interesses) movimentam o contínuo ciclo de criação e recriação.

Dessa forma, objetiva-se relacionar a teoria bakhtiniana, essencialmente associada à linguística, a aspectos da vida urbana, partindo da perspectiva de que a produção de sentido é gerada pelas experiências humanas, de acordo com cada contexto e momento histórico - o que não é diferente em se tratando de um espaço público urbano.

Olhar para a linguagem enquanto ação e interação, produto do potencial criador do homem e da sua capacidade de modificar o ambiente social, significa refletir sobre a dinâmica instaurada pela vida urbana construída na coletividade, em que a reconfiguração do espaço público resulta da linguagem em sua relação dialógica. Partindo do princípio de que essa relação compõe o tecido do espaço público urbano, este estudo demonstra que o caráter meramente físico ou transitório do espaço social e praticável é um equívoco, uma vez que a Praça possui caráter inacabado.

Essa evidência, somada ao potencial criador de cada sujeito que integra essa rede de reconfiguração simbólica e social, constitui o movimento que impulsiona o ciclo de 
contínua transformação do espaço público. No decorrer desse processo, muitas vezes, rompem-se estruturas de dominação, em que o caráter simbólico do espaço público vem à tona, enquanto fruto dos interesses dos diversos atores que o constroem diariamente.

Para tanto, este artigo está dividido em duas seções principais. Na primeira, intitulada "Dialogismo e a vida urbana", a teoria da análise dialógica do discurso de Mikhail Bakhtin é apresentada, visando relacionar a perspectiva de dialogismo e materialidade na produção de enunciados que traduzem e reconfiguram a dinâmica urbana.

Após uma apresentação introdutória sobre a teoria, inicia-se o primeiro tópico, "Luta e apropriação do espaço público urbano", em que autores contemporâneos dialogam sobre a concepção das cidades e das praças a partir do movimento de contínua transformação desencadeado pela apropriação social. Assim, a produção teórica de Milton Santos (2014), Ana Fani Alessandri Carlos (2015), Simone Scifoni (2015), Sun Alex (2008), Mauricio Abreu (2016), Andrea Cornwall (2002) e Amartya Sen (2000), debate a relação da praça pública com a produção dialógica de sentido, o que ocorre no debate estabelecido com Bakhtin (2011), Cecília Almeida Salles (2006), Marilia Amorim (2014), Adail Sobral e Karina Giacomelli (2016).

Na sequência, o segundo tópico, “A materialidade na construção de sentido", propõe uma reflexão sobre a função dialógica do signo enquanto produto da prática social, ou seja, sobre o caráter dialógico das ações humanas desencadeadas no espaço público e o teor ideológico dessas ações, bem como a materialidade resultante dessa interação.

Após o debate teórico proposto até o referido momento, inicia-se a segunda seção deste artigo, reservada às análises e apresentação do objeto de estudo em questão, a Praça Presidente Vargas. Intitulada "O caso da Praça Presidente Vargas de Pato Branco", traz elementos da história do local, na medida em que apresenta momentos de intervenção social que culminaram em diferentes transformações do espaço público, sociais e simbólicas.

A seção está dividida em dois tópicos. No primeiro, "Materialidade dialógica expressa em eventos e ações", são pontuados momentos de tensão e apropriação da Praça. No tópico seguinte, "Materialidade dialógica expressa na alteração física do espaço público", são apresentadas diferentes intervenções físicas executadas no local, por meio da interação e das necessidades das diversas esferas da atividade humana que compõem o tecido social da Praça. 
Dessa forma, busca-se estabelecer um diálogo entre autores clássicos e estudos atuais, ligados à linguagem e a ao urbanismo, que abordam, de forma direta ou indireta, o movimento de contínua configuração do espaço público, podendo, dessa forma, associar a teoria bakhtiniana a percepções ligadas a vida cotidiana das cidades enquanto produto da materialidade dialógica.

\section{Dialogismo e a vida urbana}

Reconhecer que a vida se faz no dialogismo é um dos principais ensinamentos de Bakhtin à sociedade moderna. Isso porque a relação entre o homem e a linguagem é permanente, pois a interação que o sujeito estabelece com o ambiente em que está inserido ocorre por meio da comunicação, oral ou escrita. Todavia, a forma como recebemos as influências geradas pela coletividade, por meio da linguagem, assim como o direcionamento que atribuímos ao compartilharmos nossas impressões particulares no contexto social, constituem um conjunto complexo da atividade humana que tem caráter transformador, pois pode influenciar questões de âmbito social, político, cultural, econômico e ideológico - este será, justamente, o caminho proposto neste primeiro tópico.

Primeiro, de forma breve, refletiremos sobre a noção de "dialogismo" presente na análise dialógica do discurso de Bakhtin. Quando Bakhtin (2011, p.270) reconhece o papel do outro na comunicação discursiva como elo de fundamental importância, nos convida a não analisar o mundo - tampouco partes dele - de forma isolada e unilateral. Para tanto, defende que o discurso só pode ser analisado diante de seu contexto, de forma concreta, a partir da relação entre o falante (autor) e outros participantes da comunicação discursiva (BAKHTIN, 2011, p.270).

Mas nem sempre foi assim, pois, por muito tempo, o destinatário foi reconhecido, pela linguística, apenas em seu papel de ouvinte, que possuía ação passiva em relação ao falante - este era o único protagonista do processo. Diferente dessa ideia, "o enunciado satisfaz ao seu objeto (isto é, ao conteúdo do pensamento enunciado) e ao próprio enunciador”, (BAKHTIN, 2011, p.270).

Dessa forma, só é possível agir sobre algo ao reconhecê-lo e, portanto, ao interpretar o seu significado naquele contexto. Por isso, a relação é contínua entre signos anteriores e posteriores, pois a produção ideológica dos signos ocorre a partir do processo de interação e dialogismo - vida em sociedade. De acordo com 
Bakhtin/Volochínov (2014, p.34), a consciência individual de cada sujeito forma diferentes elos com outras consciências, formando uma corrente ideológica. Afinal:

Essa cadeia ideológica estende-se de consciência individual em consciência individual, ligando umas às outras. Os signos só emergem, decididamente, do processo de interação entre uma consciência individual e uma outra. E a própria consciência individual está repleta de signos. A consciência só se torna consciência quando se impregna de conteúdo ideológico (semiótico) e, consequentemente, somente no processo de interação social. (BAKHTIN/VOLOCHÍNOV, 2014, p. 34)

Conforme aponta Marilia Amorim (2014, p. 103), o tempo articula-se com o espaço e, dessa união, forma uma unidade - que podemos, aqui, encarar também como unidade enunciativa. Mesmo na análise de uma unidade enunciativa, é preciso reconhecer a relação entre tempo e espaço, presente e passado. $\mathrm{Na}$ criação e na recriação, o movimento e a transformação integram, portanto, a dimensão do tempo este que "[...] traz consigo uma concepção de homem e, assim, a cada nova temporalidade, corresponde um novo homem".

Amorim (2014, p.103), referindo-se aos estudos de Bakhtin, evidencia, portanto, a representatividade do contexto social e mostra a complexidade presente na natureza da atividade humana, pois esta varia de acordo com o ambiente em que está inserida e representa. Afinal, o tempo habita o "campo das transformações e dos acontecimentos" (AMORIM, 2014, p, 103), o que também acompanha a história.

Esse campo, onde o tempo anterior e posterior dialogam, pode ser, perfeitamente, encarado como a Praça Presidente Vargas, uma vez que o tempo é produzido por meio da coletividade e, portanto, é produto do dialogismo. Isso fica ainda mais evidente, em Bakhtin, no livro "A cultura popular na Idade Média e no Renascimento", quando o autor menciona a praça pública como espaço acolhedor da cultura popular, conforme exemplifica Amorim (2014, p. 103, grifo nosso):

Diferentemente da literatura que trata do indivíduo e em que se encontram múltiplos tempos correspondentes aos diferentes indivíduos e às diferentes esferas de suas atividades, na cultura popular e no carnaval, o tempo é coletivo. Ou seja, o sujeito da cultura popular é o sujeito coletivo. Seu espaço é a praça pública, espaço de todos. O coletivo remete aqui a ideia de uma sociedade sem classes, em que todos compartilham do trabalho e, por conseguinte, compartilham do tempo. Tempo compartilhado, porque suposto como anterior e posterior à sociedade de classes. 
Embora refira-se a aspectos da Idade Média, a concepção de praça pública apresentada por Bakhtin (2013) contempla uma visão de lugar que recebe e incentiva a propagação da cultura popular, onde todos que nele estiverem, especialmente em dias festivos, estão munidos de liberdade para expressar suas ideias, convicções e ideologias, estabelecendo uma relação de proximidade que rompe com qualquer ordem hierárquica ou de caráter oficial; a comunicação que predominava na praça festiva, aquela que recebi a arte de rua, a mesma que estava aberta ao riso despretensioso, é a mesma que impera no âmbito familiar. Mas esse espaço transcende, inclusive, barreiras de classes dominantes e, nos dias festivos, "o vocabulário da praça pública se insinuava por toda parte, em maior ou menor medida, inclusive na igreja [...]”, (BAKHTIN, 2013, p.133).

Diferentemente da literatura que trata do indivíduo e em que se encontram múltiplos tempos correspondentes aos diferentes indivíduos e às diferentes esferas de suas atividades, na cultura popular e no carnaval, o tempo é coletivo. Ou seja, o sujeito da cultura popular é o sujeito coletivo. Seu espaço é a praça pública, espaço de todos. O coletivo remete aqui a ideia de uma sociedade sem classes, em que todos compartilham do trabalho e, por conseguinte, compartilham do tempo. Tempo compartilhado, porque suposto como anterior e posterior à sociedade de classes.

Assim, dialogismo é a ação, a experiência instituída a partir da coletividade. Mesmo em um momento de total isolamento, o indivíduo reage a partir de relações (memórias e experiências) anteriores, estas que constituem a bagagem que construiu em relação aos outros. Portanto, construção social da realidade está em constante movimento e, sendo assim, em permanente transformação, como veremos a seguir.

\subsection{Luta e apropriação do espaço público urbano}

Iniciaremos a partir da perspectiva histórica em relação a origem e evolução das "cidades" para, num segundo momento, partirmos para reflexões sobre a formação e dinâmica relacional existente no espaço público urbano "praça". Este último, por ser uma derivação da cidade e, sobretudo, por permanecer intrínseco a ela, também é produto das relações estabelecidas entre sociedade e natureza - e configura-se na maneira com que o homem, enquanto agente social, age sobre o ambiente em que está inserido.

Assim, a cidade assume diferentes formas, de acordo com os distintos momentos históricos que a transfiguram. Em cada um desses momentos, há elementos comuns, que variam em valoração, mas que existem e interferem diretamente na dinâmica de um 
município: a organização política; a estrutura de poder da sociedade; a natureza e a segmentação da economia local; e as classes sociais (CARLOS, 2015, p. 57).

Contudo, conforme alerta Milton Santos (2014, apud ABREU, 2016, p. 32), é preciso diferenciar a "história urbana" da "história da cidade". A primeira variável está ligada a reflexão realizada até aqui, pois refere-se à divisão de trabalho entre campo e cidade, às atividades não agrícolas e à organização/socialização espacial existente nas cidades. Já a história da cidade compreende os processos sociais, como os transportes, a habitação, a centralização, enfim, seria a história da materialidade da prática humana sobre a cidade. Ao unir essas duas variáveis histórias, é possível teorizar sobre a urbanização, bem como sobre a cidade, identificando ideologias, mentalidades urbanas, entre outros aspectos (SANTOS, 2014, apud ABREU, 2016, p. 32).

Portanto, considera-se que a cidade não é um produto acabado ou definitivo, pois "[...] as formas que a cidade assume ganham dinamismo ao longo do processo histórico", (CARLOS, 2015, p.57). Ou seja, o processo histórico de arranjo e rearranjo é contínuo e faz parte da construção social do meio urbano. Muito além de refletir apenas na configuração física, essa transformação reflete esferas sociais, assim como está diretamente ligada à economia local, pois:

\begin{abstract}
A história da paisagem urbana mostra os sinais do tempo que nela impregna suas profundas marcas. $\mathrm{O}$ mundo é produto do homem, da sociedade e, portanto, o espaço produzido em cada momento será concretamente diferenciado. Podemos entender o mundo sensível como produto do homem, resultado da atividade de várias gerações, cada uma ultrapassando a precedente e aperfeiçoando sua indústria, seu comércio, e com isso criando infinitamente novas formas. (CARLOS, 2015, p.58)
\end{abstract}

Contudo, há um duelo entre a preservação e recriação da história. Isso porque, de acordo com a concepção apresentada por Simone Scifoni (2015), o patrimônio histórico-cultural de uma cidade, por vezes, é encarado como negócio, característica que depende, diretamente, da intervenção do Estado. Esse conflito ocorre no momento em que um espaço urbano impede a edificação de um empreendimento privado ou infere na dinâmica de determinado local. Para legalizar tais "ajustes" físicos, políticas públicas são criadas e determinadas ações passam a ser legalizadas (SCIFONI, 2015, p.212).

Nesse processo contínuo de criação e recriação há, ainda, movimentos de ruptura, uma vez que a cidade configura-se como um campo de lutas que questionam as normas da vida urbana. Essa divisão social, somada às atividades de trabalho e produção (e reprodução) de sentido, constituem a materialidade da cidade, bem como 
das relações históricas e sociais que também contribuem no desenvolvimento dessas localidades (CARLOS, 2015, p. 26).

Mobilizações sociais em busca de direitos, bem como a relação que assumem com o espaço urbano, estão ligadas ao processo de desenvolvimento local, este que não se refere apenas a variáveis ligadas à renda ou à acumulação de riqueza. Partindo do pressuposto defendido por Amartya Sen (2000), o desenvolvimento precisa ser reconhecido não somente por questões econômicas, mas também pelas condições de qualidade de vida, do exercício das liberdades básicas e dos direitos civis. Ao usufruirmos dessa liberdade, além de interagir com o mundo, é possível influenciá-lo (SEN, 2000, p.69).

Contudo, é fundamental ressaltar a representatividade da participação popular no espaço público, não apenas como sujeito que transita diariamente por determinado local e que não imprime sua marca naquele ambiente. Ao contrário, como agentes, os sujeitos modificam a realidade local a partir das suas intervenções. Assim, o ato de participar representa a atuação direta no processo de transformação social, pois essa postura infere na esfera social e na política; é a oportunidade que a população possui de deixar de lado a passividade em relação ao Estado para, então, ser protagonista. Nesses momentos, os “[...] cidadãos criam suas próprias oportunidades e condições para o engajamento. Isto não só faz a ponte entre a participação 'social' e 'política', mas oferece novas maneiras de configurar o espaço no meio [...]”, (CORNWALL, tradução nossa, 2002, p. 02).

A expressão social presente na história da Praça Presidente Vargas enquanto objeto e instrumento da ação da população e do poder público, compõe um movimento contínuo de "dentro para fora", que "repete e refrata", mantendo assim constante diálogo entre passado e futuro. Cada novo fenômeno ocorrido nesse espaço público configura-se como resultado do dialogismo e da interação. Essa relação construiu, ao longo da história, uma complexa teia de experiências que influenciou o processo de configuração e reconfiguração, física e simbólica.

Assim, o papel que o espaço público exerce em cada ator social, reflete a dinâmica relacional da comunidade e da vida urbana. Forma-se então um ciclo entre as experiências dessas duas esferas sociais, a população e o poder público, ambas responsáveis pela transformação (e reformulação) do espaço público enquanto objeto. Isso ocorre, também, pois a percepção enquanto o "espaço público" na dinâmica urbana acompanha as transformações e as necessidades da cidade. Dessa forma: 
O espaço público na cidade assume inúmeras formas e tamanhos, compreendendo desde uma calçada, até a paisagem vista da janela. Ele também abrange lugares designados ou projetados para o uso cotidiano, cujas formas mais conhecidas são as ruas, as praças e os parques. A palavra "público" indica que os locais que concretizam esse espaço são abertos e acessíveis, sem exceção, a todas as pessoas. Mas essa determinação geral, embora diminuída ou prejudicada em muitos casos, é insuficiente: atualmente, o espaço público plurifuncional - praças, cafés, pontos de encontro - constituem uma opção em uma vasta rede de possibilidades de lugares, tornando-se difícil prever com exatidão seu uso urbano. Espaços adaptáveis redesenham-se dentro da própria transformação da cidade. (ALEX, 2008, p.17)

As transformações temporais do espaço público que, por sua vez, são incessantes, resultam da interação e do diálogo estabelecido entre os sujeitos e, portanto, não são concebidas de forma harmoniosa. Embora sejam materializadas em arenas, por meio de conflituosas relações que disputam o uso e a apropriação do espaço, promovem um profundo entendimento sobre a vida daquele contexto espaço-temporal (AMORIM, 2014, p.107). Essa apropriação temporal também é coletiva e, em seu caráter dialógico, gera materialidade e transformações contínuas, pois:

Esse tempo compartilhado, porém, se distingue também do tempo mítico, o qual se volta para um passado que é sempre o mesmo. Aqui o tempo integra o passado e o futuro mais longínquos, para ressignificá-los a cada vez. Tempo de transformações incessantes e inevitáveis, em que as gerações desempenham um papel fundamental de transmissão e de superação. Tempo que se define como grande temporalidade, pois projeta a humanidade e o mundo para um além do contexto conhecido e representado. As hierarquias e os poderes estabelecidos são contingentes e serão transformados. Esse tempo é maior do que todos porque é utópico da abertura de novas possibilidades. Renovação dos sentidos do passado e criação de sentidos futuros. Aqui, o sentido não morre, já que se inscreve em um espaço-tempo de permanente abertura às transformações. Como a terra da semeadura e da colheita, o espaço da praça pública acolhe tanto os ciclos cósmicos quanto as sucessões históricas. Aqui, a morte é o que engendra a vida e a vida é o que vai morrer. O corpo não é o corpo individual e biográfico, mas é a carne do mundo. Aqui, os ideais e os valores não pertencem a um mundo abstrato, mas se materializam e tomam forma nos elementos da vida. (AMORIM, 2014, p.103-104)

Olhar para o processo de configuração e reconfiguração do espaço público e reconhecer que, nesse caminho, feito por experiências e histórias de vida, há diferentes significações, é se deparar com a perspectiva da materialidade gerada pela ação humana enquanto "gesto inacabado". Salles (2006, p.20-21), nos mostra que a criação, enquanto capacidade inerente ao homem, compõe o movimento que impulsiona significativas e 
permanentes transformações no tecido social - este que está em constante construção, pois, por resultar da interação desencadeada pelos sujeitos, jamais estará acabado, uma vez que a completude é inatingível. Esse é um percurso de permanente mobilidade, pois o inacabamento é intrínseco a todos os processos (SALLES, 2006, p.20).

Essa perspectiva aparece tanto na construção do objeto - bem como da obra de arte - assim como se manifesta no processo de ressignificação o envolve ao longo da sua história, em diferentes momentos. Isso porque a construção está imersa na continuidade e na incompletude, em que "[...] há sempre uma diferença entre aquilo que se concretiza e o projeto do artista que está por ser realizado. [...] onde há qualquer possibilidade de variação contínua, muda ao longo do tempo", (SALLES, 2006, p.20).

Outro aspecto inerente à incompletude é o seu caráter de inter-relação com os outros, nos fazendo refletir sobre o processo de criação enquanto resultado de um ciclo formado por infinitas interações dialógicas. Estamos, portanto, nos referindo ao campo relacional, onde os componentes não podem ser isolados em suas particularidades, uma vez que a complexidade do sistema relacional é constituída pela contextualização, (SALLES, 2006, p.22) - do espaço e do tempo, bem como pelas suas variações. Nesse sentido, Bakhtin (2011, p.410), afirma que:

Não existe a primeira nem a última palavra, e não há limites para o contexto dialógico (este se estende ao passado sem limites e ao futuro sem limites). Nem os sentidos do passado, isto é, nascidos no diálogo dos séculos passados, podem jamais ser estáveis (concluídos, acabados de uma vez por todas): eles sempre irão mudar (renovandose) no processo de desenvolvimento subsequente, futuro do diálogo. Em qualquer momento do desenvolvimento do diálogo existem massas imensas e ilimitadas de sentidos esquecidos, mas em determinados momentos do sucessivo desenvolvimento do diálogo, em seu curso, tais sentidos serão relembrados e reviverão em forma renovada (em novo contexto). Não existe nada absolutamente morto: cada sentido terá sua festa de renovação. Questão do grande tempo. (BAKHTIN, 2011, p.410)

Basta reconhecer que, primeiramente, cada enunciação, até mesmo a mais completa de todas, representa apenas uma fração de uma vasta corrente que desde que recebeu seu primeiro elo, nunca mais se rompeu - e segue ganhando novos elementos. Eis a sua estabilidade, a capacidade de repetir e antecipar enunciados anteriores e posteriores. 


\subsection{A materialidade na construção de sentido}

Uma praça enquanto produto da vida urbana, possui caráter superficialmente transitório, sem grandes pretensões de causar qualquer mudança na ordem social. Todavia, enquanto signo da prática social, o lugar recebe significações que ultrapassam sua forma "natural" e o distanciam da configuração supostamente inerte. Por receber diferentes interpretações ideológicas, acaba sendo, ao longo de sua história, instrumento e objeto de ação por parte da comunidade e do poder público. Nesse contínuo movimento de ordem transformadora, ações individuais e coletivas resultam na construção de sentido, o que detona a materialidade presente na relação dialógica instituída no ambiente social. Afinal:

Os signos também são objetos naturais, específicos, e, como vimos, todo produto natural, tecnológico ou de consumo pode torna-se signo e adquirir, assim, um sentido que ultrapasse suas próprias particularidades. Um signo não existe apenas como parte de uma realidade; ele também reflete e refrata uma outra. Ele pode distorcer essa realidade, ser-lhe fiel, ou apreendê-la de um ponto de vista específico, etc. Todo signo está sujeito aos critérios de avaliação ideológica (isto é, se é verdadeiro, falso, correto, justificado, bom, etc.). O domínio do ideológico coincide com o domínio dos signos: são mutuamente correspondentes. Ali onde o signo se encontra, encontra-se também o ideológico. Tudo que é ideológico possui um valor simbólico. (BAKHTIN/VOLOCHÍNOV, 2014, p.32-33)

Conforme Bakhtin (2011, p. 271-272), "toda compreensão da fala viva, do enunciado vivo é de natureza ativamente responsiva [...]". Ou seja, é da capacidade de responder e de participar ativamente do diálogo que o ouvinte interfere no contexto e, ainda, se torna falante (autor de enunciados). Contudo, a resposta não precisa ser transmitida imediatamente; mas ela ocorre, cedo ou tarde, pois essa experiência responderá outros discursos e refletirá no comportamento social do "ouvinte". Essa "compreensão ativamente responsiva de efeito retardado" possui alto grau de importância, pois possui a mesma capacidade de interação e transformação históricosocial daquela assumida pelo falante (BAKHTIN, 2011, p. 271-272). O caráter responsivo é materializado, portanto, em ações.

Sendo assim, fica evidente a influência do discurso alheio (do outro), em relação às expressões e manifestações verbo-visuais que entoamos diariamente. Isso porque, quando entro em contato com enunciados dos outros, assim como com palavras isoladas de outras pessoas, ditas em variados contextos e situações, tais enunciados são introduzidos ao meu discurso (BAKHTIN, 2011, p.298). Embora não haja uma 
repetição exata, tais expressões são recriadas, mas não perdem a sua conexão com a história e com a sociedade. Essa variação é conduzida pela intenção discursiva e pela posição do falante empregadas em determinado momento, com determinada finalidade, acompanhando o campo da atividade humana estabelecido, pois:

Em cada enunciado - da réplica monovocal do cotidiano às grandes e complexas obras de ciência ou literatura - abrangemos, interpretamos, sentimos a intenção discursiva de discurso ou a vontade discursiva do falante, que determina o todo do enunciado, o seu volume e as suas fronteiras. Imaginamos o que o falante quer dizer, e com essa ideia verbalizada, essa vontade verbalizada (como a entendemos) é que medimos a conclusibilidade do enunciado. Essa ideia determina tanto a própria escolha do objeto (em certas condições de comunicação discursiva, na relação necessária com os enunciados antecedentes) quanto os seus limites e a sua exauribilidade semântico-objetal. Ele determina, evidentemente, também a escolha da forma do gênero na qual será construído o enunciado [...] (BAKHTIN, 2011, p.281)

A experiência discursiva individual de cada pessoa não é inédita, uma vez que é construída a partir da interação entre os sujeitos. Contudo, nesse processo de construção enunciativa, deixamos de ser meros receptores para, a partir da réplica do diálogo, recriarmos outras formas de expressão social. Portanto, frases isoladas não estabelecem relações dialógicas; os enunciados sim. "Porque todo enunciado é uma resposta, ou melhor, réplica, a outros enunciados, sejam enunciados já ditos ou não ditos, mas possíveis como resposta/réplica”, (SOBRAL; GIACOMELLI, 2016, p.1088).

É como se estivéssemos imersos em um ciclo que não é inerte, onde não somos meros repetidores, uma vez que também criamos novas experiências por meio da nossa vontade enquanto falantes (autores), bem como inserimos nossa ação à coletividade (BAKHTIN, 2011, p.294-295), num processo contínuo de criação e recriação. Mas, apesar da individualidade de cada sujeito, a carga ideológica é concebida no dialogismo e na coletividade, pois "[...] nosso discurso, isto é, todos os nossos enunciados (inclusive as obras criadas), é pleno de palavras dos outros, de um grau vário de alteridade ou de assimilabilidade [...]", (BAKHTIN, 2011, p.294-295). Todavia, damos novo sentido às “ palavras dos outros" e criamos novos enunciados, por meio da interação estabelecida no espaço social (BAKHTIN, 2011, p.294-295).

O destinatário e o contexto em que o enunciado é concebido orientam a definição do "gênero do discurso", que passaremos a analisar a partir de agora. Para tanto, primeiramente, é preciso considerar que "em cada época, em cada círculo social, em cada micromundo familiar, de amigos e conhecidos, de colegas, em que o homem 
cresce e vive, sempre existem enunciados investidos de autoridade [...]", (BAKHTIN, 2011, p.294). Por serem reconhecidos pela forte expressão e pelo tom valorativo coletivo, esses discursos dão origem a obras de arte, descobertas científicas, abordagens jornalísticas e a ideologias políticas que são citadas, imitadas e seguidas pelas pessoas. Isso ocorre porque os campos da vida e da atividade humana, são formados por manifestações condicionadas pelos "senhores do pensamento", que detêm ideias determinantes na sociedade onde estão inseridos (BAKHTIN, 2011, p.294).

Desse vínculo com a situação (contexto), a comunicação verbal/global vem acompanhada por atos sociais de caráter não verbal, conforme apresenta Bakhtin/Volochínov (2014, p. 128). Aqui, podemos identificar diversos aspectos da dinâmica da vida cotidiana, como hábitos religiosos, cerimônias, práticas de trabalho, etc. Como "atos sociais", inclusive, é possível relacionar movimentos de resistência e mobilizações que apresentam demandas sociais. Afinal, todos esses atos, quando praticados por meio da interação, culminam em transformações de ordem social que, por vezes, refletem em importantes momentos da história de determinado contexto como, por exemplo, veremos em relação à Praça Presidente Vargas.

Para elucidar essa representação, Bakhtin (2014, p.130) afirma que toda situação ou hábito que persiste por certo tempo e, assim, é concebida por sua durabilidade no contexto social enquanto "costume", possui um auditório organizado, onde um repertório de situações correntes (estáveis, que se repetem), constituem uma fórmula estereotipada que reflete "[...] ideologicamente o tipo, a estrutura, os objetivos e a composição social do grupo" (BAKHTIN, 2014, p.130). Assim, as pessoas estabelecem uma relação de interação umas com as outras, e com o espaço em que estão inseridas, a partir do meio social - no meio onde praticam suas ações, nos espaços que não são meramente transitórios, mas, sim, produto da vida cotidiana (BAKHTIN/VOLOCHÍNOV, 2014, p. 130).

O discurso tem materialidade e usa a língua, por isso é preciso reconhecer o contexto social e histórico em que foi construído, pois a produção do enunciado (e do discurso) vai além da língua concebida em dado momento - ela está inserida em um núcleo problemático, que possui história e vasto repertório simbólico. Afinal, "a frase é da língua, e o enunciado é do discurso, sendo, portanto, mais do que frase. Logo, discurso envolve interação e não somente língua". (SOBRAL; GIACOMELLI, 2016, p.1080) 
Assim, o discurso é uma unidade de análise que possui materialidade (o texto falado, escrito, as representações verbo-visuais, fotografias, etc). Essas manifestações utilizam a língua. Portanto, o discurso usa a língua para a sua concepção, por isso não pode ser confundido com o texto, com a fala ou com a própria língua. Para compreender o discurso (e identificar as unidades de análises, ou seja, os enunciados), é preciso ir além do texto ou na manifestação linguística que representa o objeto de estudo, é preciso saber "[...] quem usa a língua para se dirigir a quem, em que contexto, incluindo momento, local, interlocutores e suas relações sociais, ambiente (institucional, familiar, entre outros.) ", (SOBRAL; GIACOMELLI, 2016, p.1078).

Sendo assim, toda expressão que é dirigida a alguém, foi originada por alguma ação, sendo transmitida ou compartilhada no contexto social com algum objetivo. Cada enunciado que integra um discurso estabelece "[...] um elo real na cadeia da comunicação discursiva em determinado campo da atividade humana ou da vida", (BAKHTIN, 2011, p.288). Então, é preciso haver interação entre os sujeitos, pois a enunciação é construída pela coletividade, pela troca de experiências entre as pessoas. Um falante, sozinho, não constrói enunciados, pois os mesmos só podem ser compreendidos e inseridos no tecido social a partir do contato com outros indivíduos. Dessa interação são construídos os sentidos do enunciado, é a partir dela que ocorre a relação entre sujeitos, a interlocução. Sobretudo, “[...] a interação não é só o que acontece aqui e agora: ela vai da conversa face a face à relação entre sujeitos de lugares distintos e mesmo de épocas distintas", (SOBRAL; GIACOMELLI, 2016, p.1082).

$\mathrm{O}$ direcionamento do enunciado e a quem ele é destinado estão ligados ao reconhecimento da complexidade do campo da atividade humana. $\mathrm{O}$ enunciado sempre terá autor e destinatário, diferente de palavras e oração que, se analisadas sem expressão ou fora do contexto em que estão empregadas, são impessoais, de ninguém e endereçadas a ninguém. Há, portanto, diversas modalidades e concepções de destinatário, que influenciam diretamente a composição enunciativa, pois "cada gênero do discurso em cada campo da comunicação discursiva tem sua concepção típica de destinatário que o determina como gênero", (BAKHTIN, 2011, p.301).

Portanto, quando se propõe analisar essas interações sociais, é preciso considerar não somente o contexto da situação imediata, mas sim o "[...] histórico de interações dos interlocutores e as formas de interagir na sociedade ao longo da história", (SOBRAL; GIACOMELLI, 2016, p.1083), uma vez que as pessoas se baseiam no que ocorreu anteriormente (no passado) para agir no agora, antecipando reações, resultados 
e consequências. Se essa corrente discursiva está sendo construída ao longo da história, sendo organizada por outros enunciados, então, cada falante não é o primeiro "[...] a ter violado o eterno silêncio do universo, e pressupõe não só a existência do sistema da língua que usa, mas também de alguns enunciados antecedentes [...]”, (BAKHTIN, 2011, p.272).

Eis uma das principais concepções bakhtinianas, a de que a língua reflete e refrata. Bakhtin (2011, p.294-295) afirma que “[...] a experiência discursiva individual de qualquer pessoa se forma e se desenvolve em uma interação constante e contínua com os enunciados individuais dos outros". Essa concepção parte do princípio de que todos os enunciados possuem palavras de outras pessoas, que atribuem valor a questões sociais, cujo tom valorativo é assimilado e reelaborado a partir das percepções do sujeito, que é receptor, mas que também reproduz o seu discurso, atribuindo novas significações ao discurso pré-concebido, pois é atuante.

\section{O caso da praça Presidente Vargas de Pato Branco}

\subsection{Materialidade dialógica expressa em eventos e ações}

Em Pato Branco, a constituição da Praça Presidente Vargas condiz com a colonização da cidade. Enquanto espaço público reconhecido na dinâmica urbana como "espaço primeiro", conduziu a formação do anel central e, consequentemente, ao longo da história, tornou-se o centro da vida social pato-branquense, passando por inúmeras transformações físicas e simbólicas. Desde a sua construção inicial, na primeira metade do século XX, o local é concebido como ponto polarizador da cultura, da interação social e da relação entre sociedade e o poder público - ou seja, produto do dialogismo em seu caráter material, praticado por meio da experiência e da interação humana.

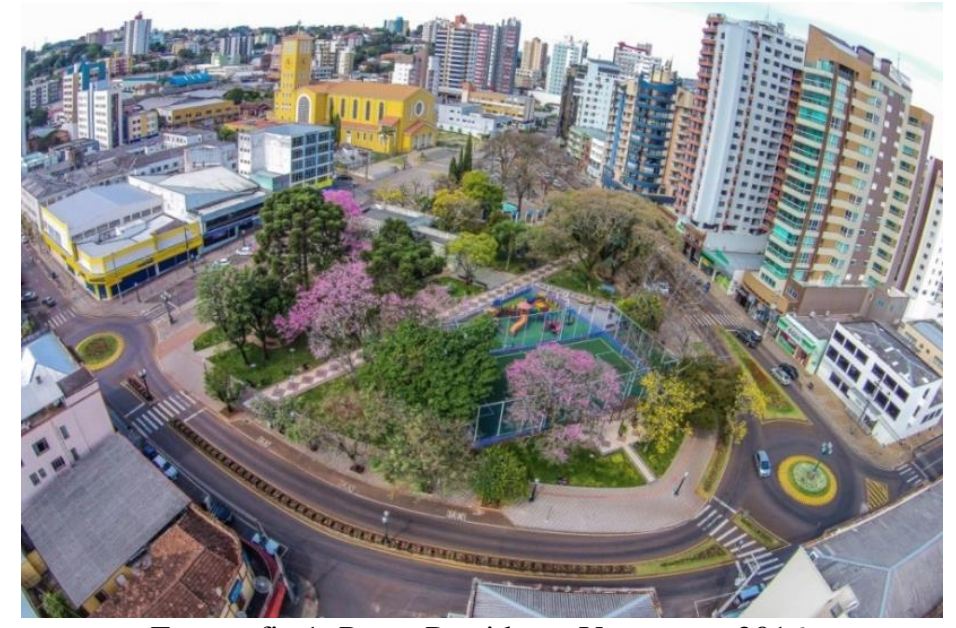

Fotografia 1: Praça Presidente Vargas em 2016.

Fonte: Acervo da Prefeitura de Pato Branco. 
Foi a decisão de padres franciscanos pela transferência da igreja da cidade, na década de 1930, que conduziu não somente a delimitação da praça, mas a formação do anel central de Pato Branco, o que fomentou a instalação de estabelecimentos comerciais no entorno do espaço (VOLTOLINI, 2005, p.83). Inicialmente, a praça foi denominada como "Praça Brasil” (VOLTOLINI, 2005, p.165). Contudo, não demorou muito para que a população passasse a chamar o espaço de "Praça Presidente Vargas", o que foi oficializado apenas mais tarde, em 25 de outubro de 1953 - quase dois anos após a emancipação política do Município - quando o então prefeito, Plácido Machado, sancionou a lei $n^{\circ} 49 / 53$, que previa a denominação de praças e ruas, entre elas a Praça "Presidente Vargas".

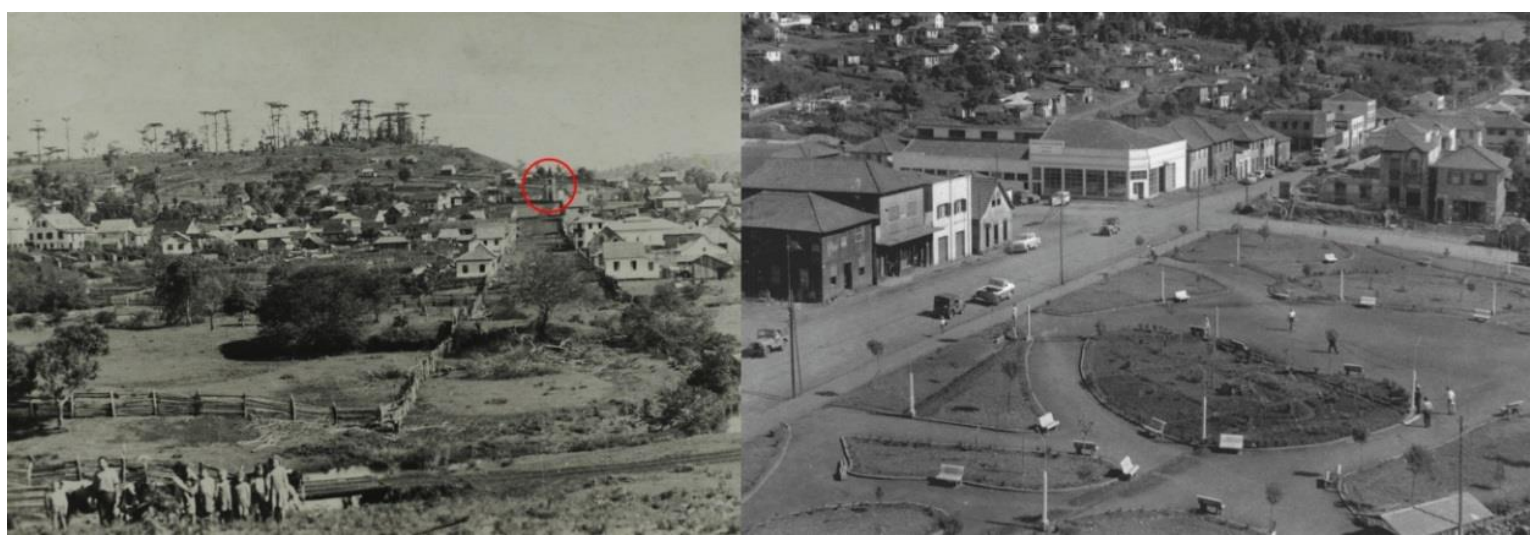

Fotografias 2 e 3: A fotografia mostra a Praça Presidente Vargas, no final da década de 1940 - é possível perceber, além da concentração de residências no seu entorno, a posição mais elevada da igreja (círculo vermelho). Na imagem ao lado, de autoria de Nelson Colla, a Praça em meados das décadas de 1950/1960. Fonte: Acervo do Departamento Municipal de Cultura de Pato Branco.

Foi na Praça Presidente Vargas, aliás, que a representatividade social dos meios de comunicação começou a despontar na cidade. Em 1948, Pato Branco ganhou seu primeiro veículo de comunicação, a chamada "Torre do Odorzick", instalada na praça central pelo candidato a deputado estadual Antonio Odorzick Filho. A torre de madeira tinha 17 metros, três potentes cornetas no alto e um estúdio completo na base. Após o período eleitoral, Odorzick deixou os equipamentos para a comunidade, que utilizou a estrutura para algo até então inédito no município: divulgar chamados, convocações, notícias e propagandas, inclusive sessões musicais, que eram realizadas aos domingos e dias festivos (VOLTOLINI, 2005, p.335).

$\mathrm{Na}$ história da praça central de Pato Branco, houve outro veículo de comunicação a estabelecer expressiva relação entre a comunidade e o espaço público. A Rádio Colméia - a mais antiga da cidade, hoje denominada Celinauta, com mais de 60 anos de existência - nos primeiros anos de existência esteve situada na rua Iguaçu, no 
entorno da Praça Presidente Vargas. O lugar tornou-se ponto de encontro dos agricultores durante a Revolta dos Posseiros, o maior movimento agrário do Sul do Brasil, que teve a Praça Presidente Vargas como palco da mobilização dos agricultores em outubro de 1957, motivados por lideranças locais e pela representatividade da rádio (VOLTOLINI, 2003, p.183).

Esse movimento se deu pelas características de apropriação das terras no Sudoeste, especialmente Pato Branco, em que boa parte dos moradores que colonizaram a cidade e a região, tomaram o território de suas propriedades sem documentar e legalizar a situação (VOLTOLINI, 2005, p.57), como foi mencionado anteriormente. Isso intensificou-se quando, em 1943, o presidente Getúlio Vargas, durante o Estado Novo, criou a Colônia Nacional General Ozório (CANGO), que mais tarde teria como sede Francisco Beltrão, cidade vizinha a Pato Branco. A nova colônia tinha como finalidade a atração de mão de obra agrícola, especialmente do Rio Grande do Sul para o Sudoeste do Paraná (WACHOWICZ, 2016, p.261).

De acordo com Wachowicz (2016, p.261), “a CANGO tinha condições para a mais perfeita colonização da história do Paraná. Em consequência, a população colonial como que explodiu. De 467 famílias em 1947, subiu para 2.725 em 1956”. Contudo, ocorreu que, no final da década de 1950, companhias passaram a reivindicar o uso e ocupação das terras, instaurando a violência por meio de barbáries cometidas por jagunços em diversas cidades do Sudoeste, com destaque para Capanema, Verê, Francisco Beltrão e Pato Branco (BONAMIGO; SCHNEIDER, 2007).

Os fatos desencadeados em 1957 resultaram em outro episódio emblemático sediado pela Praça Presidente Vargas. Em 17 de março de 1962, o então presidente da República, João Goulart, esteve no local para legalizar a situação dos colonos e entregar escrituras das terras ocupadas por pequenos agricultores. $\mathrm{Na}$ oportunidade, foi recepcionado por lideranças políticas e comunitárias (VOLTOLINI, 2003, p.309). Em ato público realizado na praça, Goulart "fez justiça", conforme a grande faixa sustentada pela população que presenciou o ato. 


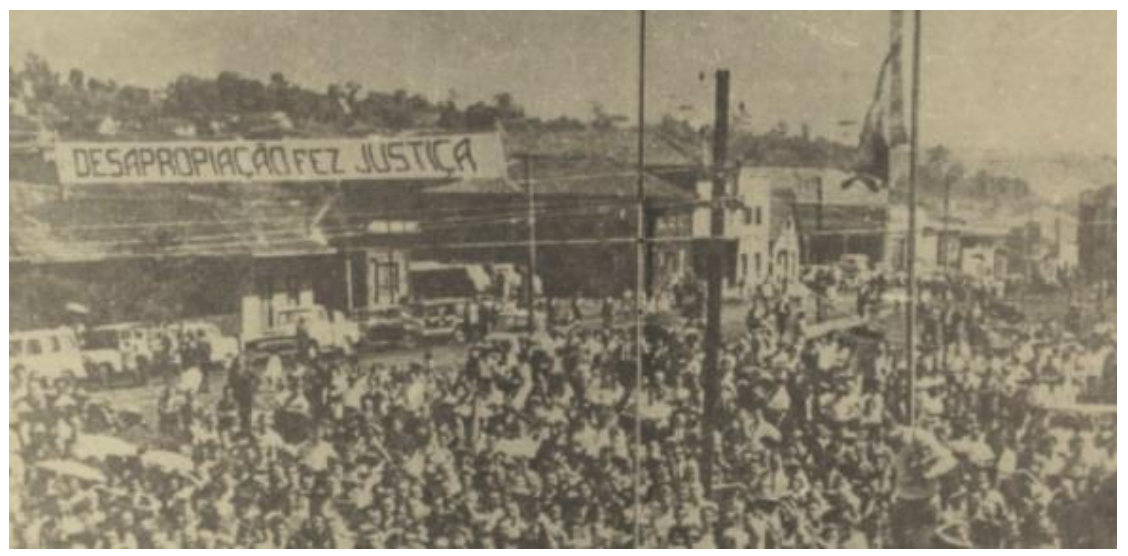

Fotografia 4: Concentração de agricultores e da comunidade em geral, na Praça Presidente Vargas, na recepção a João Goulart. Fonte: Acervo de Cirene Vanzela Miotto.

Diante do reconhecimento dos agricultores em relação à praça enquanto ponto de encontro, é preciso considerar que os campos da vida e da atividade humana acompanham tradições expressas e verbalizadas. Essas manifestações são condicionadas pelos "senhores do pensamento", que detêm ideias determinantes, que são concebidas como fundamentais para a sociedade onde estão inseridos (BAKHTIN, 2011, p.294).

Aliás, a interação e o dialogismo não estão presentes apenas nos eventos populares e nas manifestações sociais desencadeadas na praça; eles estão inseridos, sobretudo, em intervenções físicas executadas no local. A forte expressão popular que, historicamente, marcou o território do espaço público, enquanto expressão da vida cotidiana, demandou que um palco de concreto fosse construído no local - a estrutura fica nas proximidades da matriz e recebe, no decorrer do ano, diversos eventos. Ou seja, além das mensagens e reivindicações, esses episódios exteriorizaram outra importante característica da praça: o espaço público enquanto palco da cidade.

Mas o que é afinal a expressão? Sua mais simples e mais grosseira definição é: tudo aquilo que, tendo se formado e determinado de alguma maneira no psiquismo do indivíduo, exterioriza-se objetivamente para outrem com a ajuda de algum código de signos exteriores. (BAKHTIN/VOLOCHÍNOV, 2014, p.115)

Diante dos eventos citados até aqui - a criação do espaço público, suas diferentes denominações, a relação com a igreja, a Torre do Odorzick, a dinâmica estabelecida em seu torno por meio dos veículos de comunicação, o seu papel simbólico enquanto ponto de encontro durante a Revolta dos Posseiros, etc. - observa-se a apropriação popular da Praça, bem como a ressignificação em diferentes momentos da sua história, o que também caracteriza a história a cidade. É possível identificar, portanto, a presença dos gêneros do discurso, na medida em que o espaço é recriado 
pela motivação de diferentes esferas da atividade humana, cujas ações e manifestações de interesse social resultam do dialogismo em seu caráter material - a interação e a experiência coletiva, dando vida e movimento contínuo à Praça central da cidade. A seguir, veremos como essa percepção também manifestou-se em intervenções físicas que alteraram a paisagem do local.

\subsection{Materialidade dialógica expressa na alteração física do espaço público}

A paisagem arborizada com a predominância dos jardins, que caracterizava a Praça Presidente Vargas, mudou completamente após uma das principais intervenções físicas realizadas na história desse espaço público. Na gestão do prefeito Alberto Cattani, que comandou o Poder Executivo de 1969 a 1973, um novo projeto de urbanização foi executado na praça, quando foram extraídas todas as árvores cultivadas no local a partir da década de 1930.

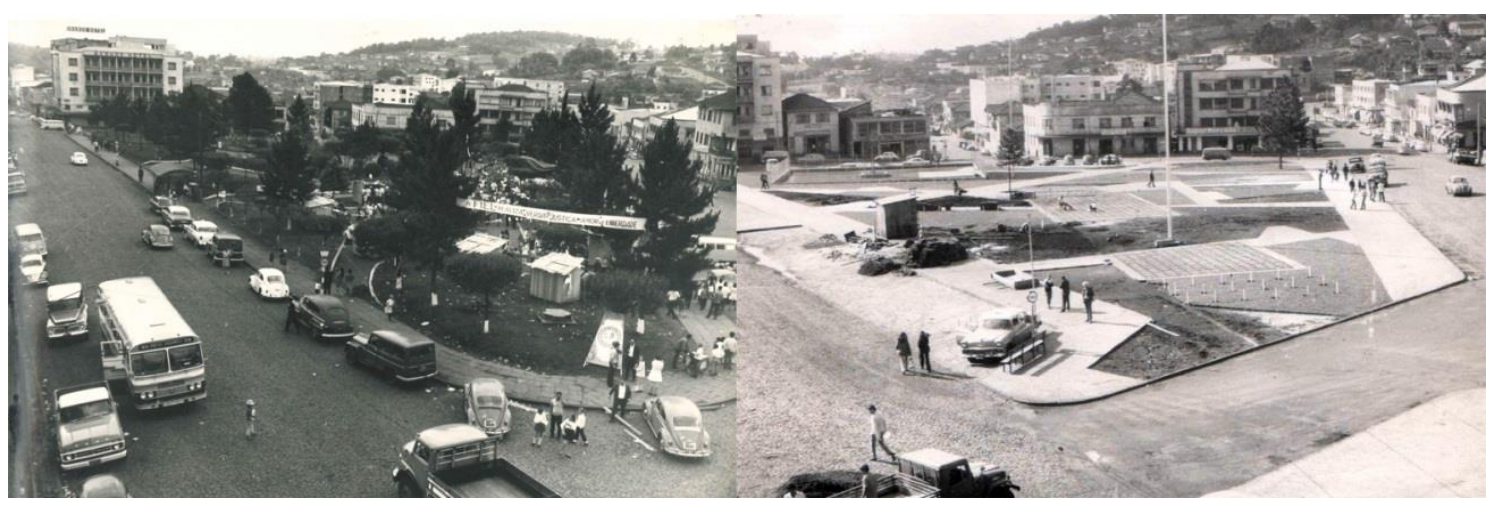

Fotografias 5 e 6: À esquerda, realização da Feira Estudantil do Livro (FIEL), na década de1960. À direita, Praça Presidente Vargas recebendo as intervenções do projeto estrutural executado na gestão do prefeito Alberto Cattani. Fonte: Acervo do Departamento Municipal de Cultura de Pato Branco.

Aqui, é importante pontuar outro aspecto relevante em relação às transformações e alternâncias desencadeadas pelo poder público. Assim como a praça está em permanente construção e reconstrução, a relação da população com o local também acompanha esse processo de mudanças. Ocorre que o signo ideológico (praça) torna-se, por vezes, instrumento de refração e de deformação do ser, diante da dominação de determinado grupo social, conforme afirma Bakhtin/Volochínov (2014, p. 48):

Mas aquilo mesmo que torna o signo ideológico vivo e dinâmico faz dele um instrumento de refração e de deformação do ser. A classe dominante tende a conferir ao signo ideológico um caráter intangível e acima das diferenças de classe, a fim de abafar ou de ocultar a luta dos índices sociais de valor que aí se trava, a fim de tornar o signo monovalente. (BAKHTIN/VOLOCHINOV, 2014, p. 48) 
Mas aquilo mesmo que torna o signo ideológico vivo e dinâmico faz dele um instrumento de refração e de deformação do ser. A classe dominante tende a conferir ao signo ideológico um caráter intangível e acima das diferenças de classe, a fim de abafar ou de ocultar a luta dos índices sociais de valor que aí se trava, a fim de tornar o signo monovalente. (BAKHTIN/VOLOCHINOV, 2014, p. 48)

Outro exemplo aconteceu em 07 de abril de $2000^{3}$, quando a Praça Presidente Vargas recebeu o "Largo das Virtudes". Todas as peças eram de autoria do escultor Kalu Chueiri, inclusive a mais polêmica, a protagonista: a escultura que tinha como proposta retratar o amor entre o homem e a mulher, na figura de um casal nu, que situava-se no centro do chafariz.

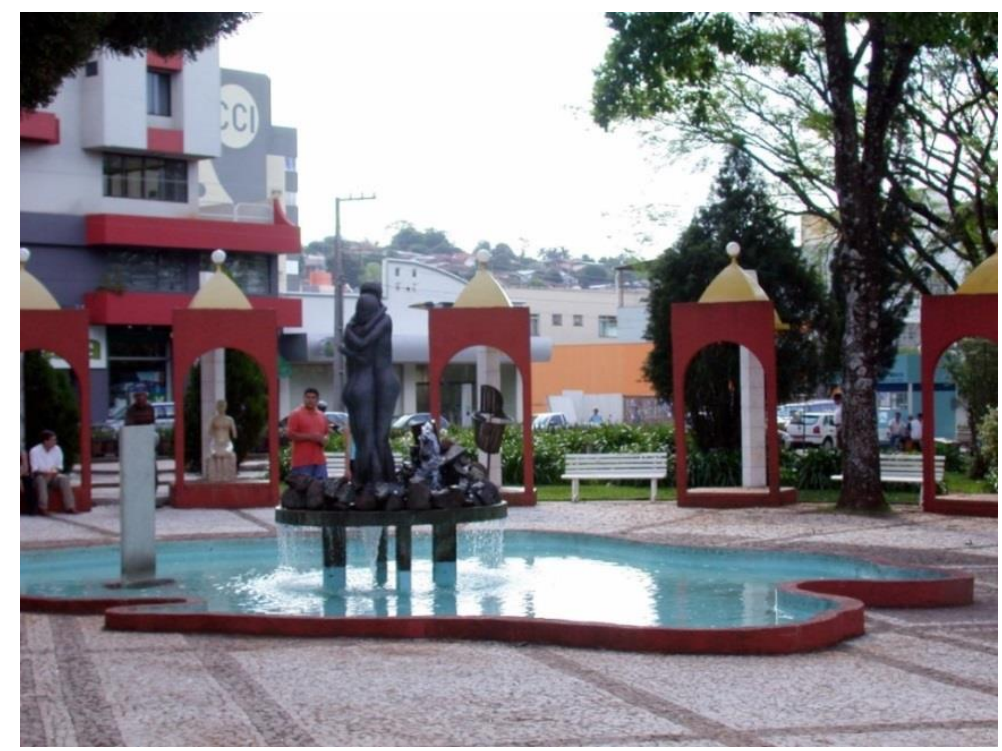

Fotografia 7: Visão do chafariz e a obra Largo das Virtudes em 2003.

Fonte: Acervo da Prefeitura de Pato Branco.

A escultura foi retirada da praça em meados de $2008^{4}$. Em matéria publicada pelo jornal Diário do Sudoeste, em 7 de dezembro de 2016, há menção ao embate popular em relação à significação da obra. O texto, com o título "O amor eternizado", diz que "por parte da comunidade, a obra, que visualmente é composta por um casal nu abraçado, foi criticada. Outra parcela da população por muito tempo se perguntou por onde andava a obra [...]”, (ROSSI, 2016, p.09).

Há, portanto, uma variação entre as interpretações ideológicas transferidas às esculturas, pois, certamente, a recepção popular à obra de arte não foi a esperada pelo poder público. Bakhtin/Volochínov (2014, p.33) justifica tal alternância, uma vez que o

\footnotetext{
${ }^{3}$ Data foi identificada por meio de pesquisa no acervo fotográfico da Prefeitura de Pato Branco.

${ }^{4}$ A matéria mencionada cita que a obra foi retirada da Praça Presidente Vargas em 2006, contudo, em pesquisa realizada junto ao acervo fotográfico da Prefeitura de Pato Branco, observa-se que a mesma ainda estava na praça até meados de 2008.
} 
domínio dos signos é acompanhado por diferentes representações ideológicas, que orientam e refratam a realidade, cada uma de acordo com o campo da atividade humana que representa. Afinal, "cada campo dispõe de sua própria função no conjunto da vida social. É seu caráter semiótico que coloca todos os fenômenos ideológicos sob a mesma definição geral”, (BAKHTIN/VOLOCHÍNOV, 2014, p.33).

Ainda nesse sentido, Bakhtin/Volochínov (2014, p.31) lembra que é importante considerar uma imagem artístico-simbólica enquanto produto ideológico, uma vez que, ao ser "[...] ocasionada por um objeto físico particular já é um produto ideológico". Dessa forma, quando o signo recebe o caráter de objeto físico, passa a representar outra realidade (BAKHTIN/VOLOCHÍNOV, 2014, p. 31). Esta, por vezes, pode representar diferentes esferas da atividade humana, juntamente com suas várias interpretações e alegorias.

A continuidade se manifesta pela variedade particular das interpretações, uma vez que cada pessoa receberá a manifestação artística de forma distinta. Salles (2013, p.95), aponta que "qualquer olhar já é um modo de ver de uma perspectiva específica e, necessariamente, não é idêntico ao objeto observado". Nesse sentido, a autora completa, explicando que "no instante de apreendermos qualquer fenômeno, já o interpretamos e naquele mesmo instante vivenciamos uma determinada representação", (SALLES, 2013, p. 95).

Dessa forma, nos resta reconhecer que essa ressignificação, resultante da apropriação social, é produto, justamente, do gesto inacabado. Isso ocorre porque a obra, assim como a praça pública que a acolheu, caracteriza-se enquanto um objeto que mesmo sendo reconhecido como "acabado", pertence, no entanto, em “[...] um processo inacabado. Não se trata de uma desvalorização da obra entregue ao público, mas da dessacralização dessa como final e única forma possível", (SALLES, 2006, p.21).

Outra importante intervenção física realizada na Praça Presidente Vargas ocorreu em 1996, com o fechamento de parte da extensão da avenida Tupi e a formação de um grande calçadão ligando a Praça à Matriz São Pedro Apóstolo. A partir disso, Praça e igreja estavam, definitivamente, unidas. De acordo com reportagem publicada na capa da edição de 22 de março de 1995, do Jornal Gazeta do Sudoeste, intitulada "Reurbanização da Tupi será por etapas", a obra ocorreria por etapas e iniciaria no ano seguinte, justificando que: 
Com o desvio do trânsito de veículos daquele trecho da Avenida Tupi, defronte à igreja, a área central da cidade ficará bem mais humanizada. A avenida melhorará bastante o seu visual, sem prejuízo para o trânsito. (GAZETA DO SUDOESTE, 1995, p.04, grifo nosso)

Embora a obra tenha alterado a dinâmica da Praça, o jornal coloca o espaço público em segundo plano, referindo-se à intervenção enquanto "reurbanização da avenida Tupi”, bem como às melhorias direcionadas ao anel central. Fica evidente, portanto, o ponto conflitante da alteração, pois as mudanças e melhorias no trânsito são enfatizadas, no texto, possivelmente antecipando o descontentamento da população ou, ainda, respondendo a questionamentos já expressados.

Assim sendo, o tema e a forma de um signo, assim como a composição de um enunciado e do seu gênero, estão diretamente ligados a fatores sociais e econômicos os valores investidos na obra e a origem dos recursos também são pontuados na notícia. Portanto, é preciso reconhecer que, segundo a análise dialógica do discurso:

O tema e a forma do signo ideológico estão indissoluvelmente ligados, e não podem, por certo, diferenciar-se a não ser abstratamente. Tanto é verdade que, em última análise, são as mesmas forças e as mesmas condições que dão vida a ambos. Afinal, são as mesmas condições econômicas que associam um novo elemento da realidade ao horizonte social, que o tornam socialmente pertinente, e são as mesmas forças que criam as formas socialmente pertinentes, e são as mesmas forças que criam as formas da comunicação ideológica (cognitiva, artística, religiosa, etc.), as quais determinam, por sua vez, as formas da expressão semiótica. (BAKHTIN/VOLOCHÍNOV, 2014, p.47)

A mesma reportagem diz que o calçadão seria uma "[...] área exclusiva para pedestres, ligando o passeio das Lojas Pernambucanas ao Banco do Brasil [...]”, ou seja, um extenso calçadão, iniciando na Rua Iguaçu, encontrando a outra extremidade destinada aos pedestres, já existente, na Rua Ararigbóia. Contudo, a intervenção que foi executada, precisou ser reformulada devido ao apelo da população. Isso porque, ao fechar a Tupi conforme previa o projeto inicial de urbanização, a obra interrompia o fluxo de veículos em dois importantes pontos do anel central: em frente à Caixa Econômica Federal, situada defronte à Praça e, ainda, prejudicando a circulação nas imediações de um grande hospital, situado na Rua Dr. Silvio Vidal, transversal à Avenida Tupi - conforme ilustrado no mapa a seguir. 


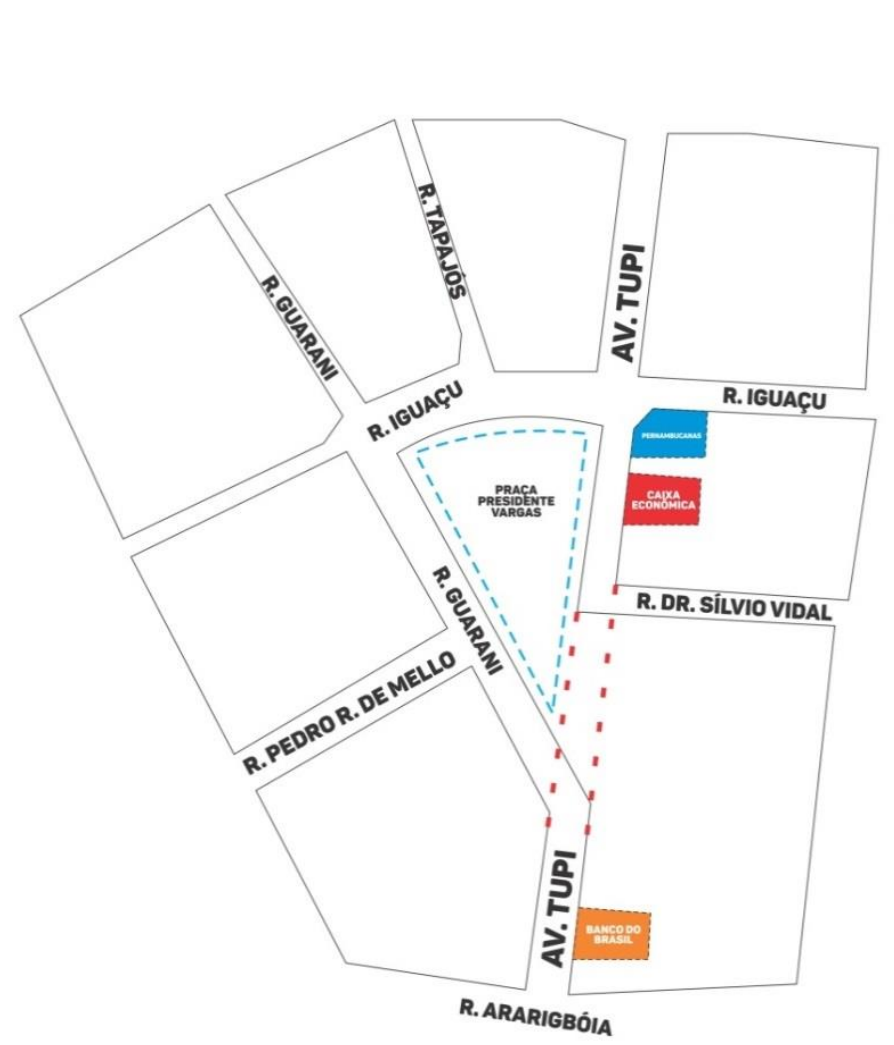

MUDANÇA NO TRAÇADO

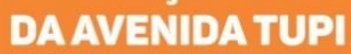

DÉCADA DE 1990

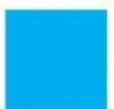

PERNAMBUCANAS

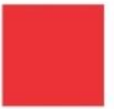

CAIXA

ECONÔMICA

BANCO DO

BRASIL

\section{TRAÇADO ORIGINAL} DAAVENIDA

Mapa 1: Ilustração criada pela autora, a fim de mostrar a alteração no traçado original da avenida Tupi, no entorno da Praça Presidente Vargas, realizado na década de 1990.

Outro exemplo da materialidade enunciativa presente no movimento de transformações físicas e simbólicas desencadeadas na Praça Presidente Vargas é a implantação da árvore digital com energia solar, instalada em outubro de 2017 na Praça Presidente Vargas, é um exemplo da tecnologia sendo utilizada pelo poder público, visando atender demandas sociais - ou interesses ligados a esferas de dominação e poder. Afinal, conforme cita Winner (1985, p.04, tradução nossa), "a história da arquitetura e urbanismo e suas obras contém um grande número de exemplos de planos físicos com propósitos políticos implícitos e explícitos [...]”.

Em matéria intitulada "Árvore digital com energia solar e sinal wi-fi gratuito é instalada em PB”, publicada no Jornal Diário do Sudoeste, na edição de 21 e 22 de outubro de 2017, consta que "a oferta de mecanismos para carregar celulares e demais dispositivos móveis, na Praça central, era uma demanda constante da população, que agora será sanada". Dessa forma, considerando também que o equipamento oferta sinal de Internet Wi-fi de forma gratuita, e dispõe de bancos para acomodar os usuários, podemos reconhecer que a iniciativa acompanha o processo de configuração e reconfiguração do espaço público. 
Essa "necessidade" foi expressa por parte da população, conforme mostra outra matéria publicada no Jornal Diário do Sudoeste, desta vez na edição de 3 e 4 de junho de 2017 - pouco mais de quatro meses antes da instalação da árvore digital. O título da notícia anuncia: "Banco da Praça é arrancado e colocado próximo à central de energia". Já no primeiro parágrafo, o texto argumenta que "um banco da Praça Central de Pato Branco foi arrancado e colocado próximo a uma central de energia, que também foi violada. O poder público constatou a ação, atribuída a vândalos […]”, (BITTAR, 2016, p.04, grifo nosso). Mais adiante, o texto apresenta que "supõe-se que o objetivo foi utilizar o equipamento para carregar celulares - e o banco colocado ali para facilitar o processo", (BITTAR, 2016, p.04, grifo nosso).

Ao indicar que o banco "foi arrancado", e não apenas "retirado", a publicação reforça a ideia, atribuída pelo poder público, de que ação foi ocasionada por um ato de vandalismo. Contudo, observa-se que tal atitude sobre o uso da Praça pública, que culminou na alternância da paisagem instituída, também pode ser observada como uma forma de apropriação popular do espaço público, pois, como a reportagem indica, outras pessoas que passaram pelo local no dia seguinte à prática, “[...] aproveitaram o improviso para dar carga em seus aparelhos".

Ou seja, o efeito responsivo presente na ação não representou uma demanda isolada, inerente apenas aos autores do ato, uma vez que outra parcela da população também fez uso da nova condição física - e por que não também "técnica" - oferecida pela Praça graças à intervenção popular.

A capacidade responsiva entre os sujeitos tem papel central na teoria bakhtiniana. Uma obra, por exemplo, é reconhecida por Bakhtin (2011, p.279) como "réplica do diálogo", pois por mais original que venha a ser, sempre terá vínculos com obras (e enunciados) anteriores e posteriores, uma vez que possui posições responsivas criadas antes e a partir da sua composição, atendendo características de um dado contexto ou campo da cultura. O papel "do outro", ou seja, da interação no processo de dialogismo e concepção de enunciados, constitui-se, portanto:

Quando o enunciado é criado por um falante, tais elos ainda não existem. Desde o início, porém, o enunciado se constrói levando em conta atitudes responsivas, em prol das quais ele, em essência, é criado. O papel dos outros, para quem se constrói o enunciado, é excepcionalmente grande, como já sabemos. Já dissemos que esses outros, para os quais o meu pensamento pela primeira vez se torna um pensamento real (e deste modo também para mim mesmo), não são ouvintes passivos mas participantes ativos da comunicação discursiva. 
Desde o início o falante aguarda a resposta deles, espera uma ativa compreensão responsiva. É como se todo o enunciado se construísse ao encontro dessa resposta. (BAKHTIN, 2011, p.301)

A evolução técnica interfere na paisagem na cidade e nos faz refletir sobre a natureza do tempo e do espaço, a partir da evolução tecnológica - o que não é um ato isolado, pois pertence a uma cadeia de acontecimentos. Aqui, não estamos falando de estradas de ferro ou da construção de novas e modernas rodovias; estamos, no entanto, debatendo sobre a representatividade simbólica de uma "árvore digital", que ao lado das árvores naturais, contribui para configurar a "nova natureza” do espaço público.

\section{Conclusão}

Longe da superficialidade da matéria meramente física, a Praça central de Pato Branco sedia, desde que foi constituída, um movimento contínuo que reúne experiências, interesses particulares ou demandas de grupos específicos. Essa relação, ao longo de oito décadas de história, foi responsável pela transformação (e reformulação) do espaço público, enquanto objeto da ação (e criação) humana.

Eis, portanto, um processo que permanece em constante movimento, devido ao caráter inacabado do espaço social, praticado diariamente pela vida e pela interação humana. Basta reconhecer que cada novo fenômeno, fruto do dialogismo, construiu, ao longo da história desse espaço público, uma complexa teia de experiências que influenciou o processo (físico e simbólico) de configuração e reconfiguração.

Resultado da prática social, essa reconfiguração, em diferentes momentos, foi conduzida por atores e esferas de poder, bem como por valores simbólicos ligados a capitais sociais. Nesse processo de apropriação, eventos, mobilizações, elementos físicos e obras de arte passaram a compor o tecido urbano e a percepção sobre esse espaço público.

Na medida em que a cidade se desenvolveu, a Praça Presidente Vargas passou a ser instrumento da ação do poder público sobre a sociedade. As diversas intervenções físicas desencadeadas no local, como exemplos de apropriação, alteraram, ao longo da história, não apenas a paisagem e a forma estrutural, mas também ressignificaram o papel social do espaço público. Assim, a Praça influencia a vida cotidiana da cidade a partir da sua dinâmica, e vice-versa, num contexto histórico repleto de lutas e mobilizações sociais. 
Portanto, a partir deste estudo, conclui-se que o enunciado é material e dialógico, pois, enquanto unidade de análise que compõe os discursos, é um produto social, que revela as relações de poder por meio dos gêneros do discurso. Para tanto, análises como esta precisam reconhecer o contexto social e histórico do objeto da enunciação, uma vez que o núcleo da ação humana é problemático e complexo, pois possui história e um vasto repertório simbólico.

Sendo assim, a teoria da análise dialógica do discurso, de Mikhail Bakhtin, mostra-se cada vez mais atual, cujo seu caráter interdisciplinar permite explorá-la em diferentes perspectivas, inclusive inseri-la na dinâmica urbana e na busca pela compreensão do movimento contínuo de criação e recriação, que caracteriza as cidades.

\section{Referências}

ABREU, Mauricio. Sobre a memória das cidades. In. CARLOS, Ana Fani Alessandri; SOUZA, Marcelo Lopes de; SPOSITO, Maria Encarnação Beltrão (Orgs.). A produção do espaço urbano: agentes e processos, escalas e desafios. $1^{\text {a }}$ ed. São Paulo: Contexto, 2016.

ALEX, Sun. Projeto da Praça: convívio e exclusão no espaço público. São Paulo: Editora Senac, 2008.

AMORIM, Marilia. Cronotopo e exotopia. In. BRAIT, Beth (Org.). Bakhtin: outros conceitos-chave. $2^{\text {a }}$ ed. São Paulo: Contexto, 2014.

BAKHTIN, Mikhail Mikhailovitch. Estética da criação verbal. Trad. Paulo Bezerra. $6^{\text {a }}$ ed. São Paulo: WMF Martins Fontes, 2011.

A cultura popular na Idade Média e no Renascimento: o contexto de François Rabelais. Trad. Yara Frateschi Vieira. $8^{a}$ ed. São Paulo: Hucitec, 2013.

BAKHTIN, Mikhail Mikhailovitch (V. N. Volochínov). Marxismo e Filosofia da Linguagem. Trad. Michel Lahud e Yara Frateschi Vieira. 16 ed. São Paulo: Hucitec, 2014.

BITTAR, Guilherme. Banco da praça é arrancado e colocado próximo à central de energia. Diário do Sudoeste, Pato Branco, 03 e 04 de junho de 2017. Cidade, p. 04.

BONAMIGO, Carlos Antônio; SCHNEIDER, Claídes Rejane (Orgs). Revisitando a história: a Revolta dos Posseiros de 1957 no Sudoeste do Paraná. Francisco Beltrão: Grafisul Gráfica e Editora Ltda., 2007.

CARLOS, Ana Fani Alessandri. A cidade. 9a ed. São Paulo: Contexto, 2015.

CORNWALL, Andrea. Locating citizen participation. IDS Bulletin Vol 33 n.2, p.49$58,2002$.

ROSSI, Marcilei. O amor eternizado. Diário do Sudoeste, Pato Branco, 07 de dezembro de 2016. Cidade, p. 09.

SALLES, Cecília Almeida. Gesto Inacabado: processo de criação artística. $6^{a}$ ed. São Paulo: Intermeios, 2013. 
Redes de criação: construção da obra de arte. $2^{\mathrm{a}}$ ed. Editora Horizonte: Vinhedo, São Paulo, 2006.

SANTOS, Milton. As técnicas, o tempo e o espaço geográfico. In. A natureza do espaço: técnica e tempo. Razão e emoção. São Paulo: EDUSP, 2008.

SCIFONI, Simone. O patrimônio como negócio. In. CARLOS, Ana Fani Alessandri; VOLOCHKO, Danilo; ALVAREZ, Isabel Pinto (Orgs.). A cidade como negócio. São Paulo: Contexto, 2015.

SEN, Amartya. Desenvolvimento como liberdade. São Paulo: Companhia das Letras, 2000.

SOBRAL, Adail. GIACOMELLI, Karina. Observações didáticas sobre a análise dialógica do discurso - ADD. Domínios de Lingu@ gem | Uberlândia | vol. 10 n.3 | jul./set. 2016 ISSN 1980-5799. p. 1076-1094.

VOLTOLINI, Sittilo. Retorno 1: origens de Pato Branco. 2.ed. Pato Branco - PR: Imprepel - Gráfica e Editora Ltda, 2005.

Retorno 2: Pato Branco na Revolta dos Posseiros de 1957. 1.ed. Pato Branco - PR: Artepres - Gráfica e Editora Ltda, 2003.

WACHOWICZ, Ruy Christovam. História do Paraná. 10. ed. Ponta Grossa: Editora UEPG, 2016.

WINNER, Langdon. Do artifacts have politics? In. MACKENZIE, D. et. al. The Social Shaping of Technology. Philadelphia: Open University Press, 1985. 


\section{Revista do Laboratório de}

Estudos Urbanos do Núcleo

de Desenvolvimento da Criatividade

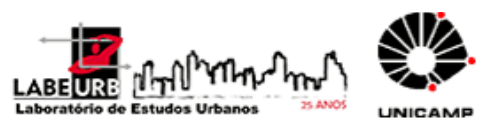

\section{Para citar essa obra:}

CARDENAL, Jozieli Camila e LIMA, Anselmo Pereira. Dialogismo, sentido e materialidade: a luta pelo espaço público urbano. In: RUA [online]. $\mathrm{n}^{\circ}$. 24. Volume $1-$ p. 183-209 - e-ISSN 2179-9911 - junho/2018. Consultada no Portal Labeurb - Revista do Laboratório de Estudos Urbanos do Núcleo de Desenvolvimento da Criatividade.

http://www.labeurb.unicamp.br/rua/

Capa: Praça Presidente Vargas em 2016.Fonte: Acervo da Prefeitura de Pato Branco.

\section{Laboratório de Estudos Urbanos - LABEURB}

Núcleo de Desenvolvimento da Criatividade - NUDECRI

Universidade Estadual de Campinas - UNICAMP

http://www.labeurb.unicamp.br/

\section{Endereço:}

LABEURB - LABORATÓRIO DE ESTUDOS URBANOS

UNICAMP/COCEN / NUDECRI

CAIXA POSTAL 6166

Campinas/SP - Brasil

CEP 13083-892

Fone/ Fax: (19) 3521-7900

Contato: http://www.labeurb.unicamp.br/contato 